\title{
Effect of Alum on the Pond Turbidity, Growth and Survival of Catla catla
}

\author{
Pankaj U. Kapse $^{1 *}$, P. E. Shingare ${ }^{1}$, S. O. Khairnar ${ }^{1,2}$, H. S. Dhaker ${ }^{1}$ and B. V. Solanki $^{1}$ \\ ${ }^{1}$ College of Fisheries, Dr. Balasaheb Sawant Konkan Krishi Vidyapeeth, Ratnagiri, \\ Maharashtra, India \\ ${ }^{2}$ College of Fisheries, Guru Angad Dev Veterinary and Animal Sciences University, Ludhiana, \\ Punjab, India \\ *Corresponding author
}

\section{A B S T R A C T}

Keywords

Alum. Turbidity, Floc, Catla, Growth

Article Info

Accepted:

12 January 2021

Available Online:

10 February 2021
Alum is more effective and economical in removing clay turbidity from pond water sample. Alum requirement test was standardized to determine the amount of alum needed to floc clay particles in pond water. Alum requirement was standardized at $27 \mathrm{mgL}^{-1}$ for pond water of Kharl and Research Station, Panvel. Alum treatment of turbid water caused marked reduction of turbidity and each $\mathrm{mgL}^{-1}$ of alum destroyed approximately $0.53 \mathrm{mgL}$ ${ }^{1}$ of total alkalinity and thereby depressed $\mathrm{pH}$. Growth and survival of Catla catla fingerlings in alum treated water compared to turbid water were studied by using ' $\mathrm{z}$ ' and ' $t$ ' test respectively. Growth parameters of 15 day catla fry and 30 day fingerlings were found to be significantly higher in alum treated clear water than turbid water, whereas no significant difference was observed in survival. In conclusion, standardized dose of alum to turbid water can be useful to achieve good growth and survival of catla seed in turbid condition.

\section{Introduction}

Among several physico-chemical variables of water, turbidity is one of critical importance as it influences aquatic life in general and commercial fish production thereby. Clay or mud turbidity is the most prevailing problem for fertilization management in fresh water ponds. Clay particles are microscopic colloids with negatively charged ions, and Brownian motion keeps these particles in suspension. Clay turbidity in pond water originates mainly from a source of water, rainwater runoff from pond dikes, erosion of pond edges, resuspension of bottom mud. As an important abiotic factor, turbidity affects growth, survival, feeding, behavior, and aquatic environment and biomass of the pond (Borok, 2010). Reduction in light penetration and photosynthesis which results in low food availability and plant biomass, reduced visibility of pelagic food and availability of benthic food due to smothering, clogging of gill rackers and filaments, reduced aerial predation risk, decreased feeding efficiency and growth are the effects of turbidity in an aquatic environment (Bruton, 1985;Zwig, et al., 1999). The reduction of turbidity by 
adding coagulant to water that facilitates the formation of bridges between particles, allowing them to combine into groups of small particles called "flocs" (Hargreaves, 1999). Alum was more effective than ferric sulfate, hydrated lime, or gypsum in removing clay turbidity from suspensions of clay (Boyd, 1979).

In this experiment a simple alum requirement test was conducted to determine the amount of alum needed to floc clay particles in pond water. Standardization of alum dose is needed as it can reduce $\mathrm{pH}$ and alkalinity of the water which could harm the fish gills and affects survival of fishes. After standardization of dose of alum to turbid pond water catla fish seed (separately for fry and fingerling) growth and survival was tested in seven replicates of each clear water (alum treated) and turbid water. The growth were tested from random samples on weekly basis to determine the growth pattern and survival was tested at the end of the experiment. During whole experiment water parameters were examined to understand and support the effects of treatment.

\section{Materials and Methods}

Experiment was carried out under Fisheries Division at Khar Land Research Station (affiliated to Dr. Balasaheb Sawant Konkan Krishi Vidapeeth), Bandar Road, Panvel, Maharashtrafor50 days. Catla seed (average size $21.98 \pm 0.2441 \mathrm{~mm}$ fry and $31.46 \pm 0.7302$ $\mathrm{mm}$ fingerlings) were collected from nursery rearing pond and acclimatized in plastic pool of 250 lit capacity five days before starting each experiment. The turbid water from nursery pond was used for rearing the fry and fingerlings of $C$. catla. Experiment was conducted in seven replicates of each alum treatment and turbid water. Fourteen circular plastic pools of 3' diameter and 2' height were used for these experiments. The acclimatized catla seed were stocked in each plastic pool at the rate of fifty animals per pool respectively.

The alum requirement test was conducted in nine glass beakers of one-liter capacity (Boyd, 1979). Sample of turbid water was collected from nursery rearing pond. Turbid water was treated with alum, aluminium sulfate $\left[\mathrm{K}_{2} \mathrm{SO}_{4}\right.$. $\mathrm{Al}_{2}\left(\mathrm{SO}_{4}\right)_{3} .24 \mathrm{H}_{2} \mathrm{O}$ ], at the increments of 5 $\mathrm{mgL}^{-1}$ to give a range of $0-40 \mathrm{mgL}^{-1}$ i.e. 0,5 , $10,15,20,25,30,35$, and $40 \mathrm{mgL}^{-1}$ by adding, stock alum solution of $2,4,6,8,10,12,14$, and $16 \mathrm{ml}$, respectively. Immediately after adding alum solution, contents of each beaker was gently stirred with glass rod for 1 minute and allowed to stand undisturbed for 2 hours to check floc point. The floc point means the $50 \%$ turbidity removal after 2 hrs was observed on graph at $27 \mathrm{mgL}^{-1}$. After stocking fish seed in pool $27 \mathrm{mgL}^{-1}$ of alum means the floc point was used for treating turbid water. Each plastic pool was gently stirred for 2 min after addition of alum, to allow proper mixing for flocculation. All 14 plastic pools in each experiment were provided with aeration, throughout the experimental period. Groundnut oil cake, rice bran, and live feed (zooplankton) were the main food for the test animals in both experiment.

The average length and weight of fry and fingerlings from alum treatment and turbid water was recorded at weekly interval from the date of stocking in both experiments. The absolute growth, relative growth, per day growth, and ponderal index were recorded at the end of experiments.

To estimate the relationship and degree of relationship of alum concentration with turbidity, $\mathrm{pH}$, total alkalinity (TA), electric conductivity (EC), total dissolved solids (TDS) co-relation and regression were used. To estimate the variation in length and weight of fry and fingerlings in alum treatment and control, ' $Z$ ' test was used. To estimate the 
average variation in survival ' $\mathrm{t}$ ' test was used in both experiment.

Turbidity, temperature, $\mathrm{pH}$, Electric Conductivity, Total Dissolved Solids were measured by using Elico Model, Water Quality Analyser, PE-138, while total alkalinity, total hardness, Dissolved Oxygen, Free Carbon dioxide were estimated by following standard method (Boyd, 1992).

In this experiment turbidity, temperature, $\mathrm{pH}$, EC and TDS were measured just before treatment. Later as, it was measured at the interval of $1 / 2,1,2,4,6,12,24$, and $48 \mathrm{hr}$ after treatment. It was further measured as every day. Other parameter such as DO, Free $\mathrm{CO}_{2}$, total alkalinity, and total hardness were estimated on every week.

\section{Results and Discussion}

Turbidity is one of the major water quality characteristics affecting fish community, resulting in dismal alteration of aquatic environment and it has been proved to have both direct and indirect effects on the growth of fish (Bruton 1985; Zwig, et al., 1999). It is apparent from the results of this study that alum treatment to turbid water samples from Kharland pond caused marked reduction in concentration of turbidity. The concentration of alum necessary to cause a $50 \%$ decrease in turbidity was considered as the floc point. Floc point was $27 \mathrm{mgL}^{-1}$ of alum for selected pond water sample and alum concentrations $5-10 \mathrm{mgL}^{-1}$ greater than floc point resulted in $60-70 \%$ removal of turbidity. Although results from different investigators were variable, many studies on the effects of alumon turbidity supported that floc points around 15 to $30 \mathrm{mgL}^{-1}$ of alum and alum concentrations 5-10 $\mathrm{mgL}^{-1}$ greater than floc points resulted in 80 to $95 \%$ removal of turbidity from most waters (Boyd, 1979; Masuda and Boyd, 1994; Hargreaves, 1999).
It means that alum @ $27 \mathrm{mgL}^{-1}$ dose was within optimum limit to reduce turbidity. Reduction in turbidity concentrations in response to alum treatment are illustrated in Figure 1.

The changes in turbidity, $\mathrm{pH}$, total alkalinity, EC and TDS are shown in Table 1. Theoretically each $\mathrm{mgL}^{-1}$ of alum destroyed approximately $0.5 \mathrm{mgL}^{-1}$ of total alkalinity, and depressed $\mathrm{pH}$. Initially water $\mathrm{pH}$ in the present study was 7.5 and it was decreasing with increased alum treatment. Boyd (1979) observed that some hydrogen ions also react with colloids, but mostly neutralise carbonate and bicarbonate and depress $\mathrm{pH}$. Alum treated at the rate of $20 \mathrm{mgL}^{-1}$ caused a 0.8 unit decline in $\mathrm{pH}$ from initial $\mathrm{pH}$ of 7.45 (Masuda and Boyd, 1994). From the results, it was observed that the alum treatment increases $\mathrm{Al}^{+3}$ concentration in water and decreases in $\mathrm{pH}$, which was recovered within $48 \mathrm{hrs}$ of alum treatment. The observations in this study were supported by theoretical assumption.

The turbidity level decreased throughout the study period in alum treatment. In 15 days fry rearing experiment the turbidity level was $7.03 \pm 0.93 \mathrm{NTU}$ in alum treated water and $171.23 \pm 2.87 \mathrm{NTU}$ in turbid water at the end of experiment shown in Figure 2. The initial concentration of turbidity was 242 NTU, while at the end of 30 days fingerling rearing experiment it was 4 and 185 NTU in alum treatment and turbid water respectively. The changes in the turbidity throughout the experimental period are shown in Figure 3.

Boyd (1979) observed that the average decrease in total alkalinity was $0.44 \mathrm{mgL}^{-1}$ for each $\mathrm{mgL}^{-1}$ of alum applied. Alum treatment of $20 \mathrm{mgL}^{-1}$ caused an $8 \mathrm{mgL}^{-1}$ decrease in total alkalinity (Masuda and Boyd, 1994). In the present study it was observed that the total alkalinity reading was found to be decreasing with increase in alum treatment, whereas 
electric conductivity and total dissolved solids showed inverse results, probably due to decrease in turbidity. In the first phase of study the $\mathrm{pH}$ was 7.58 and 7.62 in clear water and turbid water respectively, while in the second phase of study the $\mathrm{pH}$ was 6.78 to 7.34 in alum treatment and 7.14 to 7.48 in turbid water. Water $\mathrm{pH}$ ranging $6.5-9.0$ at daytime is considered well for fish growth (Boyd and Pillai, 1984). In this study, $\mathrm{pH}$ was optimum for fish growth in both the experiments which had no any severe effect on growth or survival. The average decrease in total alkalinity was $0.53 \mathrm{mgL}^{-1}$ for each $\mathrm{mgL}^{-1}$ of alum applied, which was close to the hypothetical expectation. The average decrease in total alkalinity was $0.44 \mathrm{mgL}^{-1}$ for each $\mathrm{mgL}^{-1}$ of alum applied as reported by Boyd (1979). Masuda and Boyd (1994) reported $0.40 \mathrm{mgL}^{-1}$ declines in total alkalinity for each $\mathrm{mgL}^{-1}$ of alum applied. Optimum total alkalinity requirement is $30-230 \mathrm{mgL}^{-1}$ for nursery rearing pond (Vankhede, 2002). Dissolved oxygen (DO), carbon dioxide $\left(\mathrm{CO}_{2}\right)$ and total hardness levels were found to be optimum throughout the study within clear and turbid water.

Table.1 Changes in turbidity, $\mathrm{pH}$, total alkalinity, EC, and TDS in response to alum treatment after $2 \mathrm{hr}$

\begin{tabular}{|c|c|c|c|c|c|}
\hline $\begin{array}{c}\text { Alum Treatment } \\
(\mathrm{mg} / \mathrm{lit})\end{array}$ & $\begin{array}{l}\text { Turbidity } \\
\text { (NTU) }\end{array}$ & $p H$ & $\begin{array}{c}T A \\
(m g / l i t)\end{array}$ & $\begin{array}{c}E C \\
(\mu S)\end{array}$ & $\begin{array}{c}\text { TDS } \\
(p p m)\end{array}$ \\
\hline 0 & 202 & 7.5 & 108 & 442 & 232 \\
\hline 5 & 198 & 7.5 & 104.4 & 446 & 233 \\
\hline 10 & 187 & 7.5 & 102.6 & 452 & 236 \\
\hline 15 & 168 & 7.4 & 100.8 & 453 & 239 \\
\hline 20 & 141 & 7.3 & 97.2 & 456 & 239 \\
\hline 25 & 117 & 7.2 & 95.4 & 458 & 240 \\
\hline 30 & 98 & 7.1 & 93.6 & 459 & 241 \\
\hline 35 & 87 & 7 & 91.8 & 459 & 241 \\
\hline 40 & 66 & 6.9 & 90 & 460 & 242 \\
\hline
\end{tabular}

Table.2 Lengthwise growth parameter of Catla catla fry in 15 days (mm)

\begin{tabular}{|c|c|c|c|c|c|c|}
\hline Type of Pool & $\begin{array}{c}\text { Initial } \\
\text { Length }\end{array}$ & $\begin{array}{c}\text { Final } \\
\text { Length }\end{array}$ & $\begin{array}{c}\text { Absolute } \\
\text { Growth }\end{array}$ & $\begin{array}{c}\text { Relative } \\
\text { Growth }\end{array}$ & $\begin{array}{c}\text { Per day } \\
\text { increment } \\
\text { of growth }\end{array}$ & $\begin{array}{c}\text { Average } \\
\text { Ponderal } \\
\text { Index } \\
\text { (K) }\end{array}$ \\
\hline Alum treatment & 21.98 & 28.02 & 6.04 & 0.2747 & 0.40 & $\mathbf{0 . 8 0}$ \\
\hline Control & $\mathbf{2 1 . 9 8}$ & $\mathbf{2 5 . 9 4}$ & $\mathbf{3 . 9 6}$ & $\mathbf{0 . 1 8 0 1}$ & $\mathbf{0 . 2 6}$ & $\mathbf{0 . 7 4}$ \\
\hline
\end{tabular}

Table.3 Weightwise growth parameter of Catla catla fry in 15 days (mg)

\begin{tabular}{|c|c|c|c|c|c|}
\hline Type of Pool & $\begin{array}{c}\text { Initial } \\
\text { Length }\end{array}$ & $\begin{array}{c}\text { Final } \\
\text { Length }\end{array}$ & $\begin{array}{c}\text { Absolute } \\
\text { Growth }\end{array}$ & $\begin{array}{c}\text { Relative } \\
\text { Growth }\end{array}$ & $\begin{array}{c}\text { Per day increment } \\
\text { of growth }\end{array}$ \\
\hline Alum treatment & 90.89 & 176.40 & 85.50 & 0.9407 & $\mathbf{5 . 7 0}$ \\
\hline Control & $\mathbf{9 0 . 8 9}$ & $\mathbf{1 3 0 . 5 2}$ & $\mathbf{3 9 . 6 3}$ & $\mathbf{0 . 4 3 6 1}$ & $\mathbf{2 . 6 4}$ \\
\hline
\end{tabular}


Table.4 Lengthwise growth parameter of $C$. catla fingerlings in 30 days ( $\mathrm{mm}$ )

\begin{tabular}{|c|c|c|c|c|c|c|}
\hline Type of Pool & $\begin{array}{c}\text { Initial } \\
\text { Length }\end{array}$ & $\begin{array}{c}\text { Final } \\
\text { Length }\end{array}$ & $\begin{array}{c}\text { Absolute } \\
\text { Growth }\end{array}$ & $\begin{array}{c}\text { Relative } \\
\text { Growth }\end{array}$ & $\begin{array}{c}\text { Per day } \\
\text { increment } \\
\text { of growth }\end{array}$ & $\begin{array}{c}\text { Average } \\
\text { Ponderal } \\
\text { Index } \\
\text { (K) }\end{array}$ \\
\hline $\begin{array}{c}\text { Alum } \\
\text { treatment }\end{array}$ & 31.46 & 46.32 & 14.86 & 0.4723 & 0.4953 & $\mathbf{1 . 0 0 7 0}$ \\
\hline Control & $\mathbf{3 1 . 4 6}$ & $\mathbf{4 3 . 0 8}$ & $\mathbf{1 1 . 6 2}$ & $\mathbf{0 . 3 6 9 4}$ & $\mathbf{0 . 3 8 7 3}$ & $\mathbf{1 . 0 0 4 1}$ \\
\hline
\end{tabular}

Table.5 Weightwise growth parameter of C. catla fingerlings in 30 days (mg)

\begin{tabular}{|c|c|c|c|c|c|}
\hline $\begin{array}{c}\text { Type of } \\
\text { Pool }\end{array}$ & $\begin{array}{c}\text { Initial } \\
\text { Length }\end{array}$ & $\begin{array}{c}\text { Final } \\
\text { Length }\end{array}$ & $\begin{array}{c}\text { Absolute } \\
\text { Growth }\end{array}$ & $\begin{array}{c}\text { Relative } \\
\text { Growth }\end{array}$ & $\begin{array}{c}\text { Per day } \\
\text { increment } \\
\text { of growth }\end{array}$ \\
\hline $\begin{array}{c}\text { Alum } \\
\text { treatment }\end{array}$ & $\begin{array}{c}294.72 \\
\pm 23.8576\end{array}$ & $\begin{array}{c}1000.78 \\
\pm 23.1022\end{array}$ & 706.06 & 2.3957 & $\mathbf{2 3 . 5 3 5 3}$ \\
\hline Control & $\begin{array}{c}\mathbf{2 9 4 . 7 2} \\
\mathbf{2 3 3 . 8 5 7 6}\end{array}$ & $\begin{array}{c}\mathbf{8 3 2 . 5 5} \\
\mathbf{2 9 . 8 1 5 4}\end{array}$ & $\mathbf{5 3 7 . 8 3}$ & $\mathbf{1 . 8 2 4 9}$ & $\mathbf{1 7 . 9 2 7 7}$ \\
\hline
\end{tabular}

Fig.1 Changes in the concentrations of turbidity in aliquots of a pond water sample treated with different concentrations of alum. Calculation of the floc point is illustrated

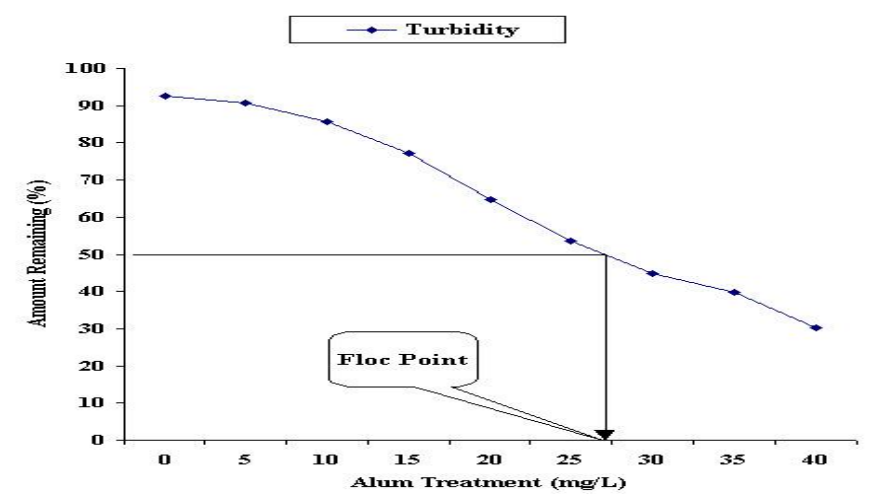

Fig.2 The average daily fluctuation of turbidity (NTU) in alum treatment and control

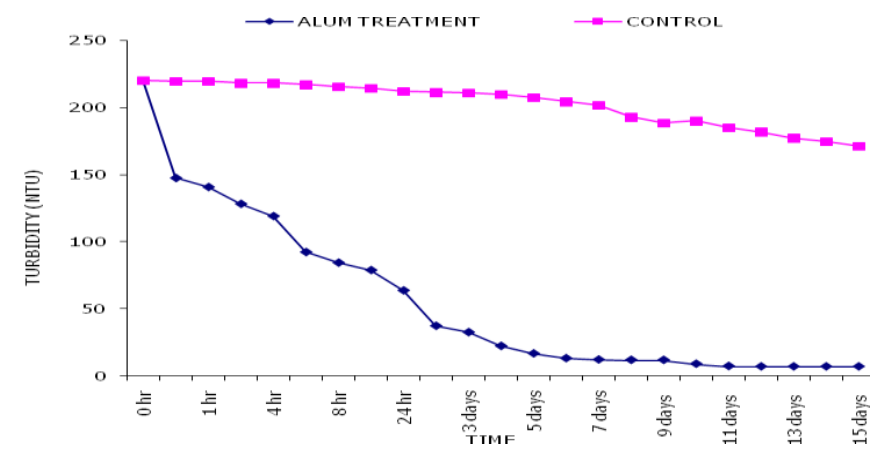


Fig.3 The average daily fluctuation of turbidity in alum treatment and turbid water

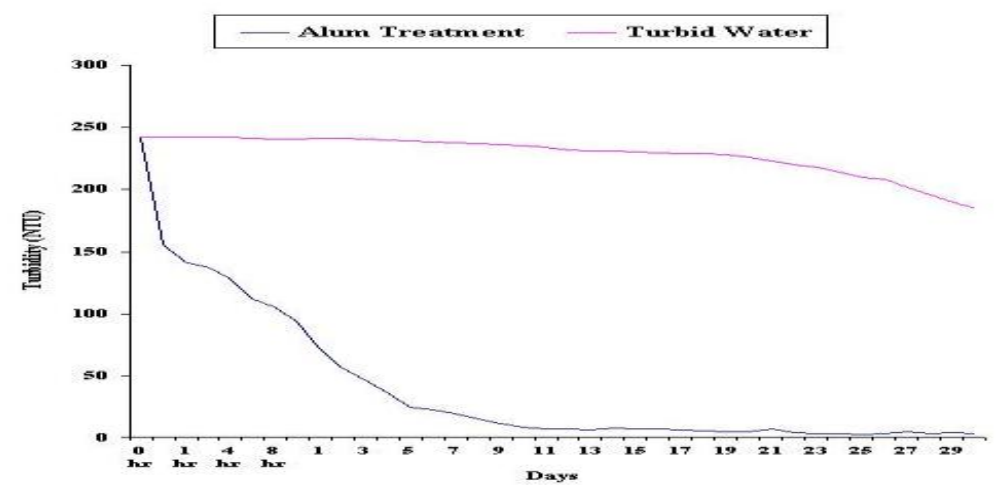

Fig.4 The weekly lengthwise growth of the $C$. catla fingerlings for 30 days

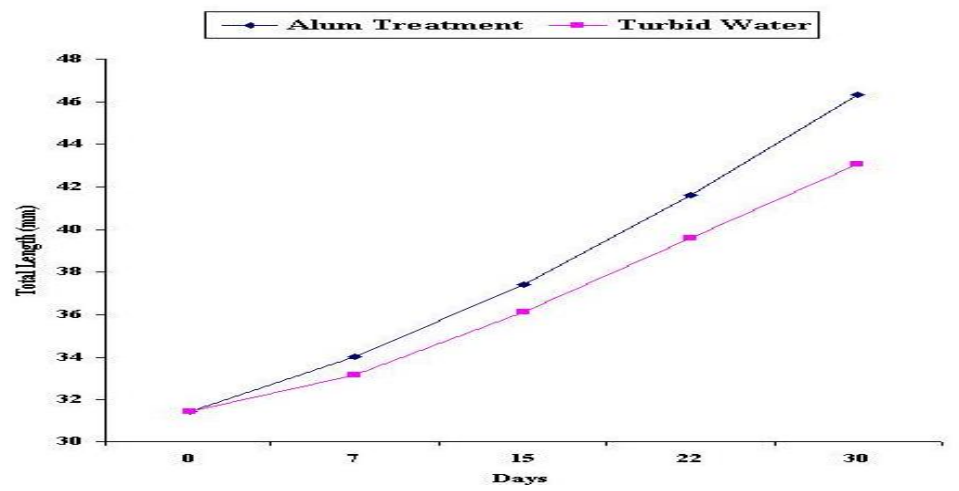

Fig.5 The weekly weightwise growth of the $C$. catla fingerlings for 30 days

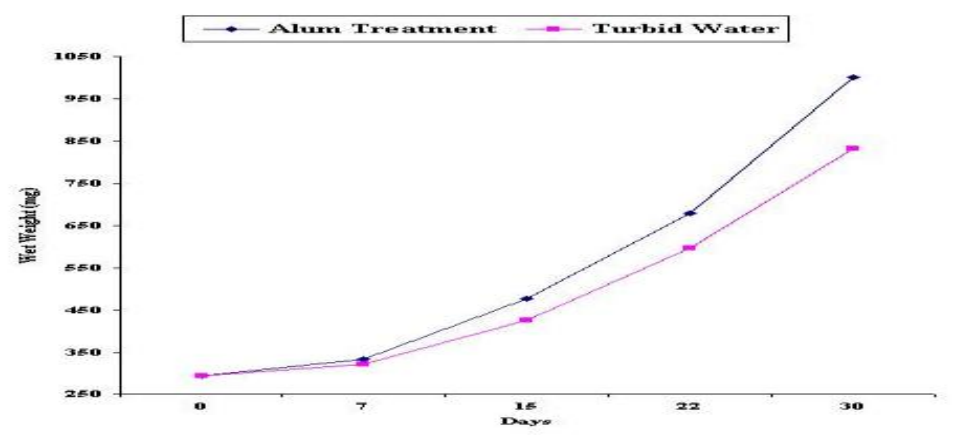

In the first experiment turbidity reading was $7.04 \pm 0.93 \mathrm{NTU}$ in alum treated water and $171.29 \pm 2.87 \mathrm{NTU}$ in turbid water. Mohanty (1992) found turbidity range $150-190 \mathrm{ppm}$ in turbid water against $0 \mathrm{ppm}$ in clear water whereas, Patnaik (1992) observed turbidity range $525-550 \mathrm{ppm}$ in turbid water and $0 \mathrm{ppm}$ in clear water. The clay turbidity levels in earthen ponds should be below $100 \mathrm{mgL}^{-1}$ (Ardjosoediro and Ramnarine, 2002). From the results of experiment, it can be seen that there was low turbidity in alum treatment which was clear visible water than turbid water. It can be seen that the lengthwise absolute growth, relative growth, per day increment and ponderal index was higher in 
clear water than turbid water (Table 2), while weight wise absolute growth, relative growth, per day increment was higher in clear water (alum treatment) than control (Table 3). The higher mean survival rate was reported in alum treatment $(80.57 \%)$ than in control (72\%). The average total biomass harvested in alum treatment and control was 49.75 and 32.89 gm respectively.

In the second experiment turbidity in turbid water was 185 NTU and in alum treated water 4 NTU at the end of the experiment, while initially it was 242 NTU in both the treatment. The overall lengthwise absolute growth, relative growth, per day increment and ponderal index was greater in alum treatment than in turbid water (Table 4). In the same way, the weight wise absolute growth, relative growth, per day increment and ponderal index was maximum in alum treatment and minimum in turbid water (Table 5). The critical difference analysis ( $\mathrm{z}$ test) revealed that the increase in length of fingerling in alum treatment was significantly higher than turbid water. The weekly lengthwise average growth $(\mathrm{mm})$ is shown in Figure 4. From the critical difference analysis ( $\mathrm{z}$ test) it is revealed that the increase in weight of fingerlings in alum treatment significantly higher than turbid water. The weekly weightwise average growth $(\mathrm{mg})$ is shown in Figure 5. The growth of fry and fingerlings reared in clear water of alum treatment and turbid water revealed that the growth (both lengthwise and weightwise) in alum treatment was always higher than that in turbid water, even though the stocking density, supplementary feed and water parameters except turbidity were same in both treatments. This indicates that there is some direct as well as indirect effect of turbidity on growth of $C$. catla fry and fingerlings.

Sigler et al., (1984) observed that, 30-65 mm long steelheads (Salmo gairdneri) and coho salmon (Oncorhynchus kisutch) subjected to continuous clay turbidities grew slower than those reared in clear water. The growth rategain of Clarius batrachus was found to be highest in the clear water followed by mixed turbidity (Sinha, 1992). Singh (1999) observed highest absolute growth of the PL of Macrobrachium rosenbergii reared in clear water as compared to turbid water. The decrease in weight gain and length gain of all male sex-reversed Jamaica red tilapia fry as turbidity increased (Ardjosoediro and Ramnarine, 2002). As in the present study, significantly lower growth was found in fry and from fingerling to fingerling stage of $C$. Catla in turbid water; the observations were comparable with above studies. This indicates that, turbid water condition is unfavourable for growth of $C$. catla and alum treatment helps to provide favourable condition by reducing turbidity.

The ponderal index was calculated at the end of the experiment and average value was found 1.0070 for alum treatment and 1.0041 for turbid water. The condition factor ' $\mathrm{K}$ ' was more than 1.0, meaning that the condition of fish and length weight proportion was good (Mohanty, 1992; Patnaik, 1992; Sinha, 1992). Gray (2011) explained that the freshwater fish $P$. multicolor was less active in turbid water.

The average total biomass harvested in alum treatment and control was 343.27 and 269.75 gm respectively. The production of juvenile coho salmon for each growth period was inversely related to quantities of fine sediment (Crouse et al., 1981). The finding of present study is supported by their study. From the results of present study, it can be predicted that the alum treatment of turbid water helps to increase the total biomass of fish.

Survival of fry after 15 days was $80.57 \%$ and $72 \%$ in clear water and turbid water respectively which was significant at $1 \%$ 
significance level, whereas survival of 30 days old fingerlings was $94 \%$ and $92 \%$ in alum treatment and turbid water respectively. There was no significant difference between survival in clear water and turbid water. Boyd (1979) observed the floc formed by alum treatment of turbid water was not toxic to fathead minnows, which were unharmed by $10-30 \mathrm{mgL}^{-1}$ alum. The result of present study was similar to their observations because alum treatment@27 mgL ${ }^{-1}$ was not toxic to fingerling of $C$. catla.

It can be summarised that the visual clarity of water must have been drastically impaired for the semi fingerling to detect the presence of their food (GOC and zooplankton) around them and at the bottom, thus, resulting in lesser consumption of the feed (GOC and zooplankton) given to them and consequently, slower growth rate. This is true even in clear water, but the decrease is much faster, in turbid conditions, because of suspended and dissolved substances, which reflect and absorb light (Bruton, 1985; Borok, 2010; VanL and eghem et al., 2011). Leahy et al., (2011) found that the fish in turbid water reducing their foraging by $40 \%$ as compared with $17 \%$ for fish in clear water. Hazelton and Grossman (2009) observed that the turbidity in water affecting fish foraging behaviour and cause habitat degradation. This is most probably a major cause of this growth variation because light intensity rapidly decreases, as it passes through turbid water. In the study all other major water quality parameters were in optimum range and also similar in both conditions except turbidity which helps to conclude that the turbid water decreases the growth of the catla fish seed which can be prevented by using alum treatment at particular standard dose to the turbid water.

In conclusion, alum is an effective coagulant for removing turbidity from pond water. The dose of alum applied for Kharland pond turbidity was $27 \mathrm{mgL}^{-1}$. The $\mathrm{pH}$ and total alkalinity declined as the alum treatment increased with temporary changes, and $\mathrm{pH}$ returned to pretreatment levels within $48 \mathrm{hr}$. The EC and TDS values increased as the alum treatment reduced the turbidity. The observations made in the present study, clearly indicated a fairly good average growth in alum treatment, as compared to turbid water, and this could be attributed to the visual clarity in alum treatment (clear water), enhancing the young fish to feed maximum on the available materials and thus, growing at faster rate than their counterparts in turbid pool. Visual clarity along with other optimum measurements of parameters in the alum treatment must have helped the $C$. catla fingerlings in attaining a good growth in alum treatment.

\section{References}

Ardjosoediro, I. and Ramnarine, I.W. (2002) The influence of turbidity on growth, feed conversion and survivorship of the Jamaica red tilapia strain. Aquaculture212: 159- 165.

Borok, A.(2010)Report-Turbidity Technical Review, Summary of Sources, Effects, and Issues Related to Revising the Statewide Water Quality Standard for Turbidity. Department of Environmental Quality, State of Oregon, 1-82.

Boyd, C.E.(1979) Aluminium sulphate (alum) for precipitating clay turbidity from fishponds. Transactions of the American Fisheries Society108: 307313.

Boyd, C.E. and. Pillai, V.K.(1984) Water Quality Management in Aquaculture CMFRI Special Publications No. 22: 511/22-48.

Boyd, C.E.(1992)Water quality management for pond fish culture, Development in 
aquaculture and fisheries science, Elsevier Science Publishers, Amstradam, Vol. 9:pp. 255-281.

Bruton, M.N.(1985) Effects of suspensolid on fish. Hydrobiologia 125: 221-241.

Crouse, M.R., Callahan, C.A., Malueg, K.W. and Dominguez, S.E. (1981) Effects of fine sendiments on growth of juvenile coho salmon in laboratory streams. Transactions of the American Fisheries Society110: 281-286.

Gray, S.M., Mcdonell, L.H., Cinquemani, F.G. and Chapman, L.J. (2011) As clear as mud: turbidity induces behavioral changes in the African cichlid Pseudocrenilabrus multicolor. Current Zoology, 58: 143-154.

Hargreaves, J.A.(1999) Control of clay turbidity in ponds. SRAC Publication no. 480, Southern

Regional Aquaculture Center, Mississippi State University.

Hazelton, P.D. and Grossman, G.D. (2009) Turbidity, velocity and interspecific interactions affect foraging behaviour of rosyside dace (Clinostomus funduloides) and yellowfin shiners (Notropis lutippinis). Ecology of Freshwater Fish, 18: 427-436.

Leahy, S.M., McCormick, M.I., Mitchell, M.D. and Ferrari, M.C.O. (2011).To fear or to feed: the effects of turbidity on perception of risk by a marine fish. Biology Letters, 7: 811-813.

Masuda, K. and Boyd, C.E. (1994) Effects of aeration, alum treatment, liming, and organic matter application on phosphorus exchange between soil and water in aquaculture ponds at Auburn, Alabama. Journal of the World Aquaculture Society 25(3):405-416.

Mohanty R.K. (1992) Effect of turbidity on the growth of fry to fingerling stage of Ctenopharyngodon idella (Grass carp). M.Sc. (Fisheries Management) Thesis. Central Institute of Fisheries Education,
Mumbai, 69 pp.

Newcombe C.P. andJensen,J.O.T. (1996) Channel suspended sediment and fisheries: a synthesis for quantitative assessment of risk and impact. North American Journal of Fisheries Management. 16: 693-727.

Patnaik S. (1992) Effect of turbidity on the growth of fry to fingerling stage of Cirrhinus mrigala (Mrigal). M.Sc. (Fisheries Management) Thesis. Central Institute of Fisheries Education, Mumbai, 75pp.

Sigler, J.W., Bjornn, T.C. and Everest,F.A. (1984) Effect of chronic turbidity on density and growth of steelhead and Coho salmon. Transactions of the American Fisheries Society113: 142150.

Singh T.(1999) Impact of turbidity on growth and survival of macrobrachium rosenbergii(de Man) post-larvae at nursery phase. M.F.Sc. (Inland Aquaculture) Thesis. Central Institute of Fisheries Education, Mumbai, 55 pp.

Sinha, R.(1992) The effect of turbidity on the growth of fry to fingerling stage of carnivorous fish (Clarias batrachus). M.Sc. (Fisheries Management) Thesis. Central Institute of Fisheries Education, Mumbai, $65 \mathrm{pp}$.

Vankhede, G.N.(2002)Management of nursery and rearing ponds. Deshmukh (Editor), Freshwater fish culture development and management, Sarup and Sons, New Delhi, 25-62.

VanLandeghem M.M., Carey, M.P. and Wahl, D.H. (2011)Turbidity-induced changes in emergent effects of multiple predators with different foraging strategies. Ecology of Freshwater Fish, 20 (2): 279-286.

Zweig R.D., Morton J.D. and M.M. Stewart, 1999. Source water quality for aquaculture, A guide for assessment. The World Bank, 7-8. 


\section{How to cite this article:}

Pankaj U. Kapse, P. E. Shingare, S. O. Khairnar, H. S. Dhaker and Solanki, B. V. 2021. Effect of Alum on the Pond Turbidity, Growth and Survival of Catla catla. Int.J.Curr.Microbiol.App.Sci. 10(02): 162-171. doi: https://doi.org/10.20546/ijcmas.2021.1002.021 